\title{
The Transformation of Jesuits Strategy for Buddhism Based on the Jesuits Works in Early Modern China
}

\author{
Peiyao Chen ${ }^{1}$ \\ ${ }^{1}$ China Aerospace Science \& Industry Corp, China \\ Correspondence: Peiyao Chen, China Aerospace Science \& Industry Corp, China.
}

Received: November 15, 2019

Accepted: December 24, 2019

Online Published: December 26, 2019

doi:10.20849/ajsss.v4i4.695

URL: https://doi.org/10.20849/ajsss.v4i4.695

\begin{abstract}
The Jesuits began their missionary work in Asia in the 16th century. After the missions in India and Japan, they tried to enter China and spread Catholicism at the end of the 16th century (Note 1). Due to the special political and cultural environment of China at that time, the missionary experience of Jesuits in India and Japan did not fully apply to Chinese society, which caused their missionary process to be rocky (Note 2). In order to adapt to the different environment of the Ming dynasty, Jesuits had to actively adjust their missionary strategies. After a period of observation and exploration, Jesuits used a missionary method of preaching through books in Ming and Qing dynasties (Note 3). Therefore, the adjustments of their missionary strategies are also reflected in their Chinese missionary works, including the adjustments of Jesuits' evaluation of Buddhism in their Chinese missionary works, which is a question worthy of attention and research.
\end{abstract}

Keywords: Jesuits, missionary work, Buddhism

The attitudes of the Jesuits who came to China to preach in the 16th century towards Buddhism reflected in their Chinese works are inconsistent, changing over time and situation. In the early days of mission, the Jesuits represented by Michele Ruggieri still maintained their understanding of Buddhism that they had gained from their mission in Japan (Note 4). They accordingly borrowed Buddhist clothing and terminology to try to open the door to China (Note 5). However, with the development of missionary work, Jesuits represented by Matteo Ricci moved more towards the Confucian scholars and dressed in Confucian clothing. They gradually removed the Buddhist terminology that easily confused Catholicism and Buddhism in their works, and refuted Buddhist theories in their writings and speeches (Note 6). This article attempts to prove that the attitude of the Jesuits toward Buddhism in their writings changed with the social conditions and different reactions of the Chinese, especially the Chinese scholars.

After the Jesuits entered China, they had a varied engagement with Buddhism, including both borrowing from Buddhism and criticising it Buddhism, probably because Buddhism was quite powerful in China in that period (Note 7). Since the Jesuits wanted to spread Catholicism, they needed to engage with the influence of Buddhism in China.

In the late Ming Dynasty, Buddhism had a significant influence in China. After being introduced to China during the Han Dynasty, Buddhism gradually completed its own Chineseization in the Sui and Tang Dynasties after long-term adjustment and adaptation, and became a universal religious belief rooted in Chinese society (Note 8). Its various ideas and concepts permeated the spirit world of Chinese people. The extensive and enormous influence of Buddhism in the Chinese culture prompted the emperors to follow the traditional Confucian rules and also to regard Buddhism as an important ideological tool for managing the people (Note 9). This is the fundamental starting point for the rulers with regards to fundamental policies for Buddhism. The rulers of the Ming Dynasty basically followed this policy (Note 10). This made Buddhism became the one of the most important religions of the Ming Dynasty. Buddhism in the Ming Dynasty was prominent and popular, surpassing Taoism and other religions (Note 11).

While Buddhism held an important position in Chinese society, it had a very low position in the eyes of most Chinese Confucian scholars (Note 12). Due to the huge investment of emperors to build countless temples and to hold Buddhist activities and the proliferation of monks caused by the royal family's worship of Buddhism, there were many negative political, economic and social consequences (Note 13). From the perspective of Confucian scholars, the emperors deviated from the so-called 'teachings of the sages' (圣贤之道) which indicated the 
thoughts of sages and men of virtue, so the ministers always requested the emperor to stay away from Buddhism (Note 14). In addition, Buddhist monks did not produce and did not pay taxes. Some destitute monks harassed the residents around the temple and even committed crimes (Note 15). This led to the fact that the lowest level of ordinary Buddhist monks still did not receive respect. Consequently, although Buddhism has many believers in the Ming Dynasty, Buddhist monks are still in a low position in the most Confucian scholars and Chinese people who are deeply influenced by Confucian culture. Therefore, the influence of Buddhism in the late Ming society and its complicated social status led to the Jesuits to make a series of adjustments to their missionary activities after entering China.

As soon as the Jesuits tried to teach in China, they took notice of Chinese Buddhism, although initially they had a relatively superficial understanding of Buddhism. During this period, the Jesuits' understanding of Buddhism basically came from their missionary experience in Japan. Alessandro Valignano (1539-1606), an Italian Jesuit, arrived in Japan in 1574 and worked hard to find ways to preach in Asia. When he was inspecting in Macau, he asked to send a priest to take charge of the missionary work in China. This person was finally selected as Michele Ruggieri (Note 16). Valignano asked missionaries to make some adjustments to the method of preaching to adapt the Chinese culture. He proposed: that 'as soon as the missionaries settle down, they should wear Buddhist monks' robe to highlight the religious nature of the mission' (Note 17). His request came from his understanding during his inspections in Japan. In Japan, he saw that the status of Japanese Buddhist monks was very high, and they were also prestigious among the people, and were regarded as a higher cultural class in Japan (Note 18). Therefore, when Buddhist monks were regarded as the upper echelons of society, it was understandable that the Jesuits wanted to preach with the Buddhist robe.

The situation of Japanese Buddhism has had a great influence on the early Ruggieri mission in China. Ruggieri was the first Jesuit to be approved to live in mainland China, and he was also the first Jesuit to write a Catholic teaching book in Chinese (Note 19). The writing about Buddhism by Ruggieri and other Jesuits who first entered China reflects their missionary strategies during this period. Ruggieri was not only dressed like a Buddhist, but also used Buddhist terminology repeatedly in his Chinese works during the preaching (Note 20).

In order to obtained legal and formal residency rights in China, Ruggieri repeatedly requested Chen Rui who was the Governor of Guangdong and Guangxi (Note 21). Because of the religious nature of the jesuits, Chen Rui thought that the Jesuits were no different from Buddhist monks and placed them in Tianning Temple in 1582 (Note 22). Besides, because of the poor reputation of Portuguese businessmen in China, Chen Rui, who controlled the entry and exit of the personnel, only saw these missionaries as 'Buddhist monks' in order to found a reason for their settlement in China (Note 23). On February 7, 1583, Ruggieri mentioned in a letter to his superiors that local officials wanted to see them wearing the Buddhist monks' clothing. Ruggieri and others accepted this suggestion, and began to dress up as Buddhist monks (Note 24). This image change has received very good results, and Chen Rui agreed to their request to apply for a place of residence (Note 25). The Jesuits used Buddhist robes to show their religious identity and to draw a line with the poorly-reputed Portuguese merchants, effectively alleviating the hostile attitude of Chinese officials and civilians. After some twists and turns, in August 1583, the Chinese local government allowed the Jesuit missionaries to live in mainland China for the first time (Note 26). In summary, Because of the non-secular characteristics of Buddhism, the Buddhist monks were able to enjoy the relative freedom to enter and exit the country even under conservative foreign policy. This is a long-established convention in China (Note 27). In the eyes of officials, 'Buddhist monks' are recluses. Their arrival would not bring troubles to the country. Therefore, Jesuits began to play Buddhist monks at the beginning as a compelling choice to settle in China.

In addition, Ruggieri's experience at Tianning Temple gave him an opportunity to have direct contact with Chinese Buddhism (Note 28). Through close observation of the monks and the background knowledge gained from Japan, Jesuits found some similarities between Catholicism and Buddhism, such as Buddhist monks acknowledging another 'trinity' (three treasures: Buddha, Buddhist Scripture and Buddhist monks) and the existence of heaven and hell. Buddhists often practice hardships, and their etiquette and teachings have similarities with Christianity (Note 29). The Jesuits mistakenly believed that Buddhist monks were similar to European church monks and Japanese Buddhist monks as well as having a high political and social status, so they follow the advice of Chinese officials and used the image of 'Buddhist' as their initial identity. In addition, they frequently used Buddhist vocabulary in their missions.

The Jesuit missionary strategies for China during this period can be seen in the work of Ruggieri. For example, in the 'Chinese Poetry Collection' written by Ruggieri in Chinese, there are two poems. The contents are as follows: 
Two Poems written while in residence at the Tianzhu si for Some Gentlemen

I (僧) came to China from Tianzhu (天笈 which means India),

And experienced three years of hard years.

I specially studied the sage book,

And prepared to promote Catholicism to people.

(Second poem)

On a small barge I set sail from the seashore,

And came to China after a three years' voyage;

Like autumn water my mind is always clear and bright;

My body is like a bodhi (菩提) so how can there be flowers?

If you do me the honor to allow me to stay,

Forthwith shall I take up my abode.

And if you ask me about the things of the Western paradise (西天 which also means India in Chinese),

My explanation is not that of Buddha Sakya (Note 30).

These two poems reflect the contradictions and entanglements of Ruggieri. On the one hand, he introduced himself and Catholicism in Buddhist terms, such as calling himself '僧', both of which are self-proclaimed by Buddhists. And saying that he comes from 'Tianzhu' (天笈) which means ancient India in Chinese. Moreover, the words 'Bodhi' (菩提) and 'West' (西天) with Buddhist characteristics are also used in the poem. On the other hand, he did not want the Chinese to confuse the Catholicism and Buddhism in the poems and try to distinguish between these two different religion. So at the end of the poem, although he said that he came from the 'West' (西天 which also means India in Chinese), he stressed that it was not the hometown of Shakyamuni, he makes effort to emphasise that he does nott have the same explanation as Buddha Sakya, in other words that he is offering something very different, particialyarly about the western paradise.

In addition, Ruggieri also used existing Buddhist terminology to explain Catholic doctrine in Ruggieri's most important book: 'The New Records of Catholic Saints in Western Country'(新编西箨国天主实录) (1584). 'The New Records of Catholic Saints in Western Country' is the work of Ruggieri's propaganda of Catholic teachings, and the first missionary book written in Chinese by the Jesuits in China (Note 31). As the main achievement of Ruggieri's mission in China, 'The New Records of Catholic Saints in Western Country' naturally reflect his attitude towards Buddhism and his missionary strategy. Just like the two poems in the 'Chinese Poetry Collection' mentioned above, he also used the Buddhist terms in this book. For example, he said: 'Although I (僧) was born in a foreign country, I am also a human being like you ...... I came from Tianzhu (天竺). I heard about the reputation of China and voluntarily endured the risks at sea. It took three years to reach the Ming Dynasty.' (Note 32) These few words explain where Ruggieri came from and why he wanted to come to China. Like the two poems mentioned above, Ruggieri also uses the word '僧', which is often used by Buddhists, when he introduces himself. And he translates his hometown into '天竺'. This word is one of the ancient Chinese titles to India which is the cradle of Buddhism.

Ruggieri uses Buddhist terminology in his work, not only because the Jesuits had limited knowledge of Buddhism when they first entered China, but also because Ruggieri saw Buddhism as a stepping stone to China, claiming that Buddhists might dispel the doubt and rejection of local officials and people. As mentioned before, his main purpose was to express the non-secularity of the Jesuits and to show the difference with Portuguese merchants. For the Ming Dynasty, which has been shutting down for a long time, it is impossible to accept a pagan team to change the people's beliefs in China, but is possible to let these Jesuits exchange Buddhist scriptures in China as a Buddhist from the West (Note 33).

However, the use of '僧' indicated that Ruggieri did not mind connecting himself to Buddhist monks at that period, but naturally this did not mean that he adhered to Buddhism since his whole reason for being in China was to promote Catholicism. He therefore only chose very superficial ways in which he connected himself with Buddhism After he gradually gained a foothold in Zhaoqing, he began to try his best to explain his position that he did not agree with the Buddhism (Note 34). Ruggieri's denial of Buddhist teachings was also expressed through the book 'The New Records of Catholic Saints in Western Country' (新编西竺国天主实录). For example, he said: 'There are many spirits and gods in the universe, not only Tianzhu (天主 which specifically means the god of the Catholic Church in Chinese) (Note 35). Some people said that the heavens and the earth are 
supreme, and the rest of the creatures are just ordinary. Other people also said that Sakyamuni became a true God. Others believe that there is no god in this world, and the development of things depends on fate ...... However, in this world, only Tianzhu (天主) is supreme, is the only true God in the world. Lord in charge of all things in the universe, there is no need for other gods. Just as a person has only one head, there is only one parent in a family, and there is only one monarch in a country. So I (僧) believe: Tianzhu (天主) is the only true God' (Note 36). In these few sentences Ruggieri tried to explain that although there were many spirits in the universe, such as Sakyamuni. They were not the one true God. Only Tianzhu (天主) is the true God. These words show that although Ruggieri does not mind borrowing Buddhist terminology to promote Catholicism, he still does not want the Chinese to confuse Buddhism with Catholicism. He still emphasizes the uniqueness of Catholicism.

Although Ruggieri denied some Buddhist teachings that contradicted Catholic doctrine in his most important work, he still used Buddhist terminology throughout the process. For example, even when he criticized Buddhist scriptures, he still called himself '僧', a Buddhist. The use of Buddhist terminology was quickly banned by Matteo Ricci, however.

Matteo Riccio (1552-1610) entered China in 1581 (the ninth year of the reign of Emperor Wanli). He has made outstanding achievements in the history of Chinese Catholic missions (Note 37). He wrote many Chinese works among which were many Buddhist remarks in the works such as 'The True Meaning of the Lord of Heaven' (天 主实义) (Note 38). This article will next focus on Matteo Ricci's remarks about Buddhism, and use this to analyze their attitude towards Buddhism and the corresponding missionary strategies during this period.

When Ricci first followed Ruggieri into Zhaoqing in 1583, he also dressed as a Buddhist monk like Ruggieri. For the Jesuits who were not familiar with China, relying on the foundation of Buddhism in China was an expedient measure (Note 39). However, Ricci and other Jesuits who claimed to be the 'Buddhists from the West' during this period encountered some difficulties. Not only the government was very unfriendly to them, and the local people were also very reluctant to these Jesuits, and several attacks against them occurred (Note 40). Ricci found that Ruggieri's method of borrowing Buddhist terminology could reduce the local people's defense against them, but the effect of mission is not obvious. Moreover, in the process of his interaction with the Chinese, he gradually discovered that the status of Buddhists in China was not as high as that of Japan (Note 41). This is very unfavorable for their mission.

In 1589, local officials suggested Matteo Ricci and others went to the famous Buddhist temple Nanhua Temple in Zhangzhou. At this time, Ricci knew that Chinese officials still regarded them as Buddhists. At this point, Matteo Ricci began to tell local officials and Buddhist monks that the Jesuits believed in Catholicism which was different from Buddhism (Note 42). In other words, the Jesuits did not want to confuse themselves with Buddhists. From this period, Matteo Ricci had abandoned the identity of Buddhist monks and began to emphasise the difference between Buddhists and Catholic missionaries. Because Ricci gradually discovered in his contact with the Chinese, the true believers in Buddhism are the lower classes (Note 43). As mentioned before, although Buddhism has many believers in the Ming Dynasty, Buddhists are still in a low position in the eyes of most Confucian scholars and the Chinese people who were deeply influenced by Confucian culture (Note 44). In a letter that Matteo Ricci wrote to the Macau priest Duarte de Sandein 1595 (Note 45), Ricci talked about the low status of Chinese Buddhist monks and used it as a reason why they began to dress up as Confucians (Note 46).

With increased contact with the Chinese, Ricci realized that he needed to enter the mainstream society in order to preach in China (Note 47). Therefore, he needed to learn Confucianism with humility. Thereafter, Matteo Ricci accepted the advice of the literati, took off the Buddhist clothing, and changed the Chinese Confucian clothing (Note 48). This change greatly improved the treatment of the Jesuits. After that, Ricci's letter to the priest Duarte de Sande mentioned the change in attitudes of local officials: Previously, local officials were not keen on their presence, but they treated them warmly after they changed to Confucianism clothing (Note 49). Ricci's change of attitude toward Buddhism was not only reflected in his costumes, but also in his Chinese works. Ricci changed Ruggieri's strategy of using Buddhism to promote Catholicism, he removed all the Buddhist terms used in Ruggieri's 'The New Records of Catholic Saints in Western Country'(新编西竺国天主实录) and strongly criticized Buddhism in his other books.

There is a later version of Ruggieri's book 'The New Records of Catholic Saints in Western Country'(新编西笈 国天主实录), the title of this version is 'Veritable Records of Catholic Saints' (天主圣教实录). This version was originally collected in the Vatican Apostolic Library, cataloged as Borg Chinese 324 (1), and was signed as '耶稣 会后学罗明坚述，同会阳玛诺、费奇规、孟儒望重订' which indicated that 'written by Jesuit Scholar Ruggieri, renewed by Emmanual Diaz Junior, Gaspard Ferreria and Joannes Monteiro' (Note 50). Regarding the question 
of who edited these two versions, Chinese scholar Li Xinde has already analyzed it in his article. Through the research and analysis of the letters of Ruggieri and Matteo Ricci, and comparing the different publishing times of the two versions, he concluded that the first version 'The New Records of Catholic Saints In Western Country'(新编西䇥国天主实录) was written by Ruggieri, and the second version 'Veritable Records of Catholic Saints' (天主圣教实录) was not the first edition of Ruggieri's early creation in China, but the Jesuits represented by Matteo Ricci re-written in order to move closer to Confucianism after leaving Guangdong in $17^{\text {th }}$ century (Note 51). The second version removed the vocabulary related to Buddhism to avoid confusion between the two religions, and adapted the style of writing to make it more appealing to Confucian scholars.

The list of Christian terms that have been partially modified in these two versions is as follows:

\begin{tabular}{|c|c|c|c|c|}
\hline \multirow[t]{2}{*}{ Version } & \multicolumn{2}{|l|}{ 新编西竺国天主实录 } & \multicolumn{2}{|l|}{ 天主圣教实录 } \\
\hline & $\begin{array}{l}\text { Original } \\
\text { Text }\end{array}$ & Translated Text & $\begin{array}{l}\text { Original } \\
\text { Chinese Text }\end{array}$ & Translated Text \\
\hline Signature & 天竺国僧 & $\begin{array}{l}\text { The Buddhist from } \\
\text { India }\end{array}$ & $\begin{array}{l}\text { 耶稣会后学罗 } \\
\text { 明坚 }\end{array}$ & Jesuit Scholar Ruggieri \\
\hline $\begin{array}{l}\text { Self-proclaim } \\
\text { ed }\end{array}$ & $\begin{array}{l}\text { 僧、天国僧书、教 } \\
\text { 门之僧 }\end{array}$ & $\begin{array}{l}\text { Self-proclaimed by } \\
\text { Buddhists }\end{array}$ & 余 & $\begin{array}{l}\text { Self-proclaimed by Chinese } \\
\text { intellectuals }\end{array}$ \\
\hline Hometown & 天竺、天竺国 & India & 西国 & Western country \\
\hline Dwelling & 寺 & Buddhist temple & 天主堂 & Catholic church \\
\hline
\end{tabular}

It is not difficult to see from the new version of language and content that Jesuits of this period tried to distinguish between Catholicism and Buddhism, and to highlight their Catholic identity, and the words were more inclined to Confucianism. For example, the Jesuits' name for themselves is no longer a Buddhist monk's self-proclaimed '僧', but becomes a '余' and ‘先生' which are self-proclaimed by ancient Chinese Confucian scholars and intellectuals (Note 52). This is a reflection of the major changes in the missionary strategy of the Jesuits and the attempt to eliminate the influence of Ruggieri's early mission through Buddhism (Note 53). The missionary strategy of the Jesuits led by Matteo Ricci at this stage can be reflected in Ricci's main Chinese works.

In Ricci's main Chinese book 'The True Meaning of the Lord of Heaven' (天主实义), he criticized Buddhism from many new perspectives. For example, he accused Buddhist teachings of imitating the Western reincarnation theory, and negated Buddhist doctrine from the roots of it. He pointed out that Buddhism was introduced to China at the same time that the apostles were spreading the teachings of Christ.. The Chinese at that time heard the truth in the Gospel of Christ and were deeply touched by these truths, and they urgently wanted to have a deeper understanding of it. Therefore, people went to the West to seek truth. However, due to the mistakes of court, or other aspects, the Chinese mistakenly found Buddhism (Note 54). Ricci further pointed out that there were many similarities between Catholicism and Buddhism because the Buddhist doctrine was a copy of the Western Pythagorean reincarnation theory, and it was also mixed with the Taoist doctrine.

The strategy of Matteo Ricci's criticism of Buddhism really made the Jesuit missionary process in China enter a new stage (Note 55). Under the efforts of Matteo Ricci, Yang Tingyun who had always believed in Buddhism turned to Catholicism (Note 56). He was born into a devout Buddhist family and was a government official. After he met Matteo Ricci in 1600, he was gradually attracted by the knowledge of Western science and theology brought by Matteo Ricci, and eventually converted to Catholicism (Note 57). However, Buddhism had a deep foundation in China. After the publication of 'The True Meaning of the Lord of Heaven', the large-scale criticism of Buddhism caused suspicion and resentment among some officials and Buddhist scholars (Note 58). The situation was tense. In the face of strong opposition, Matteo Ricci can only accept the suggestion of Xu Guangqi (徐光启) who was a Chinese Catholic convert, scholar-bureaucrat, astronomer, agricultural scientist, and mathematician in the Ming dynasty (Note 59). So as to weaken the dislike of church in all classes of Chinese (Note 60). In his later works, Matteo's attitude towards Buddhism was softer than before.

Ricci sorted out the conversations with some Chinese from 1589 to 1607 and edited them into a book, which was published in 1608. This book was called 'Ten Chapters of a Strange Man' (畸人十篇) which was completed after seven years of publication of 'The True Meaning of the Lord of Heaven' (Note 61). 'Ten Chapters of a Strange Man' and 'The True Meaning of the Lord of Heaven' as Ricci's works in different periods, they have something 
in common. For example, they all use the structure of dialogue between Chinese scholars and Western missionaries to preach Christian teachings; they all contain some negative comments on Buddhism.

It is worth noting that Matteo Ricci's evaluations of Buddhism are very different in these two books. As mentioned before, Matteo Ricci fundamentally denied the credibility of Buddhism from various angles in 'The True Meaning of the Lord of Heaven'. The dialogue in this book is full of strong scent of gunpowder. In the text, it can see that Ricci often uses 'evil' and 'heretical' to describe Buddhism. For example, in the seventh chapter, Matteo Ricci told Chinese: '... Buddhism is a heresy. The more people worship the Buddha, the more sinful people are' (Note 62). When Ricci talked about the Buddhist scriptures, he often described it as: 'Hypocritical heretical scriptures, empty and exaggerated words' (Note 63) or 'ignorant and fatuous words' (Note 64). The 'heaven' in Buddhism was 'coarse and primitive' (Note 65), the Buddhists were 'rabble' and they were deceived by Buddhism (Note 66).

However, not only was the content evaluating Buddhism greatly reduced in 'Ten Chapters of a Strange Man', but Ricci's tone of talking about Buddhism was also more euphemistic. The words, such as 'heretical' or 'cults' that often appeared in 'The True Meaning of the Lord of Heaven' basically did not appear in this book. In Ricci's evaluation of Buddhism, the strongest word used was 'stealing' which appeared in the eighth chapter, Ricci tried to prove that Buddhist reincarnation theory was 'stolen' from the Catholic heaven and hell theory (Note 67). In this book, Ricci did not directly deny Buddhism, Buddhist scriptures or Buddhas, but he euphemistically raised doubts about the Buddhist traditions, thus achieving his goal of demeaning Buddhism. Ricci mostly raised questions about Buddhism in a sloppy way. For example, in the sixth chapter, in order to raise doubts about the fasting of Buddhism, Ricci said: 'The Chinese did not believe Buddhism before the Tang Dynasty when Buddhism had not entered China. During that period, people used cattle, sheep and pigs to worship ancestors and gods, they were not afraid to kill livestock. During the sacrifice, the participants could not drink alcohol and cannot eat meat. Nowadays, the scholar-officials still have to quit drinking and eating meat during the sacrifice... Therefore, the theory of fasting did not originate from Buddhism. (Note 68)' Ricci first proposed that the habit of fasting always existed in ancient China, and tried to prove that the fasting doctrine of Buddhism was not original. Through this statement, he reached the goal of denying Buddhism by inference. It showed that Ricci no longer directly described Buddhism and Buddhist scriptures as 'heretical' and 'fatuous words', but tried to prove the falsehood of Buddhism to the Chinese in a roundabout way in this book. This kind of devious and euphemistic teaching method runs through the whole book. In another word, it is difficult to see Ricci in a logical way to prove some arguments, such as 'God controls everything' or 'Buddhism is heresy' in this book. Moreover, it is also difficult to see the sharp opposition between the worldview and values of both China and the West (Note 69).

The above analysis has clearly shown the huge differences in the evaluation of Buddhism from the form to the content in the two works of Matteo Ricci. The reason why Matteo Ricci's evaluation of Buddhism has changed is mainly due to his deepening understanding of Chinese society and the changes he has made due to the pressure exerted by some officials and Buddhist scholars (Note 70).

After the publication of 'The True Meaning of the Lord of Heaven', the large-scale commentaries and attacks on Buddhism caused suspicion and resentment among some officials and Buddhist scholars (Note 71). The situation was tense. For example, Matteo Ricci wrote in his letter that the Buddhism in Zhejiang Province was very powerful. A Chinese official Yu Yuxi once advised him not to criticize Buddhism again: 'One scholar wrote me a long letter asking me not to oppose the Buddha. Otherwise there would be a scourge. (Note 72)'

In the face of strong opposition, Matteo Ricci accepted the suggestion of Xu Guangqi (Note 73) and took measures as soon as possible, he wished to weaken China's dislike of church. 'Ten Chapters of a Strange Man' written after 'The True Meaning of the Lord of Heaven' only stated that Catholicism and Buddhism were different, and the criticism of Buddhist reincarnation and fasting theories was overtaken (Note 74). The remarks of Ricci's work on Buddhism attracted the attention of some Buddhists. After his death, Chinese anti-Catholic activities became fiercer (Note 75). The works written by other Jesuits after this are more about discussing issues in the field of inner self-cultivation and morality, and the condemnation of Buddhism in their writings is more euphemistic.

In conclusion, the different reactions of the Jesuits to Buddhism, including the initial reference and the subsequent attack, were the adjustment of their missionary policies by the Jesuits based on their gradual deepening of their understanding of the Chinese and different social situations. When the Jesuits first carried out missionary activities in China, because of Chinese exclusion of strange religions, they misunderstood that Chinese officials regarded them as Buddhist monks. Jesuits used the influence of Buddhism in China to promote 
Catholicism. Nevertheless, Jesuit could not recognize any other religion because they thought all others were wrong. Therefore, after the conditions were ripe, they launched an attack on /Buddhism. However, when the missionaries discovered that their speech did not achieve the intended purpose and instead caused a rebound in Chinese society, they promptly toned down their militant criticism of Buddhism. Instead, they focused on social ethics and moral cultivation, which would be appreciated by Chinese Confucian scholars (Note 76). The changes of position on Buddhism in the works of the Jesuits in China were only due to the need for missionary work. Jesuits adjusted their speeches on Buddhism and missionary strategies rapidly according to the social situation at the time and the different reactions of the Chinese people. The reals reason was to obtain the support of the Chinese and to achieve the goal of more widespread conversion Chinese. After all, activities they have done in China were help to serve their missionary career.

\section{References}

Criveller, G. (1997). Preaching Christ in Late Ming China: The Jesuits' Presentation of Christ from Matteo Ricci to Giulio Aleni.

Du, C. (2005). On Relations between the Ming Imperial Court and Buddhism.

Fei, L. (1995). The Jesuit Biography in China.

Gao, S. (2014). Ricci's knowledge spread and belief spread. Journal of Beijing Administrative College, 2, 21-34.

Gernet, J. (1982). China and the Christian Impact: A Conflict of Cultures (J. Lloyd translated).

Hsia, R. (2010). A Jesuit in the Forbidden City: Matteo Ricci 1552-1610.

Li, X. (2005). From the Western Monks to the Western Confucian: the Predicament of the Early Jesuits in China. Journal of Shanghai Teachers University, 1, 87-92.

Liu, Y. (2015). The Dubious Choice of an Enemy: The Unprovoked Animosity of Matteo Ricci against Buddhism. The European Legacy, 20, 224-238.

Liu, Y. (2001). The True Pioneer of the Jesuit China Mission: Michele Ruggieri. History of Religions, 5, 362-383.

Ricci, M. (1986). The Collection of Ricci's Letter (L. Yu translated).

Ricci, M. (2000). Ten Chapters of a Strange Man (畸人十篇). In A. Zheng (Ed.), The Collection of Jesus Thoughts and Documents of the Late Ming and Early Qing Dynasty (明末清初耶穌會思想文獻匯編) (vol. $3)$.

Ricci, M. (2000). The True Meaning of the Lord of Heaven (天主实义). In A. Zheng (Ed.), The Collection of Jesus Thoughts and Documents of the Late Ming and Early Qing Dynasty (明末清初耶穌會思想文獻匯編) (vol. 2).

Ricci, M. (2014). Jesuit And Catholic Church Enters Chinese History (Z. Wen translated).

Ricci, M., \& Trigault, N. (2010). Matteo Ricci’s Reading Notes about China (Z. He and G. He translated).

Ricci, M., et al. (1998). Veritable Records of Catholic Saints (天主圣教实录).

Ross, A. (1994). A Vision betrayed : the Jesuits in Japan and China, 1542-1742.

Ruggieri, M. (2000). The New Records of Catholic Saints in Western Country (新编西竺国天主实录). In A. Zheng (Ed.), The Collection of Jesus Thoughts and Documents of the Late Ming and Early Qing Dynasty (明末清初耶穌會思想文獻匯編) (vol. 1).

Scott, K. (1929). A History of Christian Missions in China.

Wu, Y. (2016). Preaching Though books: A Method of Missionary Work in Chinese Society Adapted to the Ming and Qing Dynasties. Research on the History of Publishing in China, 7, 21-37.

Xiao, R. (1989). The History of Catholicism in China.

Xu, Y. (2014). A Comparative Study of The True Meaning of the Lord of Heaven (天主实义) and Ten Chapters of a Strange Man (畸人十篇). Catholic Church in China, 2, 10-15.

Zhao, T. (2007). A Discussion on the Religious Policies of the Ming Dynasty. The Journal of Ancient Civilizations, 2, 68-87. 


\section{Notes}

Note 1. K. Scott, A History of Christian Missions in China, (London, 1929), p.83.

Note 2. Y. Wu, 'Preaching Though books: A Method of Missionary Work in Chinese Society Adapted to the Ming and Qing Dynasties', Research on the History of Publishing in China, 07 (2016), pp.21-37.

Note 3. Wu, 'Preaching Though books', pp. 21-22.

Note 4. A. Ross, A Vision betrayed: the Jesuits in Japan and China, 1542-1742. (Edinburgh: 1994). pp. 79-117.

Note 5. R. Hsia, A Jesuit in the Forbidden City: Matteo Ricci 1552-1610. (Oxford: 2010). pp. 80-81.

Note 6. Y. Liu, 'The Dubious Choice of an Enemy: The Unprovoked Animosity of Matteo Ricci against Buddhism', The European Legacy, 20 (2015), pp. 224-238.

Note 7. Y. Xu, 'A Comparative Study of The True Meaning of the Lord of Heaven (天主实义) and Ten Chapters of a Strange Man (畸人十篇)', Catholic Church in China, 02 (2014), pp. 10-15.

Note 8. Xu, 'A Comparative Study', p.10.

Note 9. T. Zhao, 'A Discussion on the Religious Policies of the Ming Dynasty', The Journal of Ancient Civilizations, 02 (2007). pp. 68-87.

Note 10. C. Du, On Relations between the Ming Imperial Court and Buddhism, (Jinan: 2005).

Note 11. Ibid, p. 5.

Note 12. Ibid, p. 150

Note 13. Ibid, p. 189.

Note 14. Du, On Relations between the Ming Imperial Court and Buddhism, p. 190.

Note 15. Ibid, p. 191.

Note 16. Ross, A Vision betrayed, pp. 32-46.

Note 17. G. Criveller, Preaching Christ in Late Ming China: The Jesuits' Presentation of Christ from Matteo Ricci to Giulio Aleni, (Michigan: 1997)., pp. 47-50.

Note 18. Ibid, p. 45.

Note 19. Hsia, A Jesuit in the Forbidden City, p. 97.

Note 20. Ibid, pp. 97-98.

Note 21. Y. Liu, 'The True Pioneer of the Jesuit China Mission: Michele Ruggieri', History of Religions, 05 (2001), pp. 362-383.

Note 22. R. Xiao, The History of Catholicism in China, (Shanghai: 1989), p. 111.

Note 23. Xiao, The History of Catholicism in China, p. 112.

Note 24. Ricci and Trigault, Matteo Ricci's Reading Notes about China, p. 131.

Note 25. L. Fei,The Jesuit Biography in China, (Beijing: 1995), p. 25.

Note 26. Xiao, The History of Catholicism in China, (Shanghai: 1989), p. 25.

Note 27. S. Gao, 'Ricci's knowledge spread and belief spread', Journal of Beijing Administrative College, 02 (2014), pp. 21-34.

Note 28. Xu, 'A Comparative Study', pp. 10-15.

Note 29. J. Gernet, (J. Lloyd translated) China and the Christian Impact: A Conflict of Cultures, (Cambridge: 1982), pp. 110-111.

Note 30. Hsia, A Jesuit in the Forbidden City, pp. 97-98. The original text: 寓杭州天竺诗答诸公二首 僧从西 竺来天矢，不惮驱驰三载劳。特把圣贤书读罢，又将圣教度几曹。一叶扁舟泛海涯，三年水路到中华。 心如秋水常涵月，身岂菩提那有花。贵省肯容吾着步，贫僧到处便为家。诸君若问西天事，非是如来佛 释迦。

Note 31. X. Li, 'From the Western Monks to the Western Confucian: the Predicament of the Early Jesuits in China', Journal of Shanghai Teachers University, 01 (2005), pp. 87-92.

Note 32. Ruggieri, ‘The New Records of Catholic Saints in Western Country' (新编西竺国天主实录), The original text: 僧虽生外国, 均人类也......僧生于天竺, 闻中华盛治, 愿受风波沿海, 三载方到明朝. 
Note 33. X. Li, 'From the Western Monks to the Western Confucian: the Predicament of the Early Jesuits in China', Journal of Shanghai Teachers University, 01 (2005), pp. 87-92.

Note 34. Ibid, pp. 87-91.

Note 35. He borrowed an unusual Chinese term, Tiānzhǔ (天主, Lord of Heaven) to describe the God of Abraham, despite the term' $\mathrm{s}$ origin in traditional Chinese worship of Heaven.

Note 36. Ruggieri, 'The New Records of Catholic Saints in Western Country’ , p. 19. The original text: 宇内 灵神极多, 不特天主, 或有者言曰: 天地至尊, 非余物之叱; 亦有者言曰: 释迦弥陀真成道果; 又有言 者曰: 世界并无灵神, 凡事皆由乎命.......答曰: 僧见尊友, 略明诸经.......主最灵, 独有一位, 掌握宇内 事物, 何须其多哉。譬如一人止有一首, 一家止有一长, 一国止有一君, 假如有二, 则国家乱矣。僧故 曰: 天主独尊.

Note 37. J. Brucker, 'Matteo Ricci', The Catholic Encyclopedia, 08 (2017).

Note 38. Li, 'From the Western Monks to the Western Confucian', pp. 87-92.

Note 39. K. Tang and X. Zhou, 'Four Issues in the Dissemination of Matteo Ricci's World Map during the Ming Dynasty', Studies in the History of Natural Sciences, 03 (2015), pp. 294-315.

Note 40. Gao, Late Ming Jesuits' Comments on Buddhism, pp. 18-19.

Note 41. Gao, Late Ming Jesuits' Comments on Buddhism, pp. 16-17.

Note 42. Ibid, p. 19.

Note 43. Ibid, p. 27.

Note 44. Ibid, p. 190

Note 45. Portuguese Jesuit, rector of the college at Macao; sometimes referred to as Eduardus de Sande.

Note 46. Gao, Late Ming Jesuits' Comments on Buddhism, p. 19.

Note 47. Ibid, p. 20.

Note 48. Gao, Late Ming Jesuits' Comments on Buddhism, p. 21.

Note 49. Ibid, p. 32.

Note 50. Li, 'From the Western Monks to the Western Confucian', pp. 87-91.

Note 51. Li, 'From the Western Monks to the Western Confucian', pp. 87-91.

Note 52. M. Ricci and other Jesuits， 'Veritable Records of Catholic Saints’（天主圣教实录), (Beijing: 1998).

Note 53. Ibid, pp. 89-91.

Note 54. M. Ricci, ‘The True Meaning of the Lord of Heaven’ (天主实义), in A. Zheng (eds.), The Collection of Jesus Thoughts and Documents of the Late Ming and Early Qing Dynasty (明末清初耶穌會思想文獻匯編), (Beijing: 2000), volume two. The original text: 夫谁以为空? 空之说, 汉明自天竺得之。佛家西窃闭他卧刺 劝诱愚俗之言, 而衍之为轮回; 中窃老氏刍狗万物之说, 而衍之为寂灭一切, 尘芥六合; 直欲超脱之, 以为高中国圣远。

Note 55. Liu, 'The Dubious Choice of an Enemy', pp. 224-238.

Note 56. Gao, Late Ming Jesuits' Comments on Buddhism, p. 16.

Note 57. Ibid, p. 17.

Note 58. Y. Liu, 'Adapting Catholicism to Confucianism: Matteo Ricci’s Tianzhu Shiyi', The European Legacy, 01 (2014), pp. 43-59.

Note 59. Brockey, Journey to the East, p. 59.

Note 60. Gao, Late Ming Jesuits' Comments on Buddhism, pp. 18-19.

Note 61. Xu, 'A Comparative Study', pp. 10-15.

Note 62. Ricci, 'The True Meaning of the Lord of Heaven’ (天主实义), p. 82. The original text: 惟此异端, 愈祭拜尊崇,罪愈重矣。

Note 63. Ricci, ‘The True Meaning of the Lord of Heaven’ (天主实义), pp. 82-83. The original text: 异端伪 经, 虚词诞言。

Note 64. Ibid, p. 97. The original text: 佛家西窃闭他卧刺劝诱愚俗之言...... 
Note 65. Ibid, p. 48. The original text: 所言佛氏之国,闻见必真,其国之婳如彼也......

Note 66. Ibid, p. 92. The original text: 夫以金木泥铸塑不知何人伪像, 而倡愚讯往拜祷之......

Note 67. Ricci， ‘Ten Chapters of a Strange Man’ (畸人十篇), p. 487. The original text: 佛氏窃闻吾西方天 堂地狱之说......

Note 68. Ricci， ‘Ten Chapters of a Strange Man’ (畸人十篇), p. 470. The original text: 中国自三代以前, 佛 教未入, 悉不奉佛也, 皆以太牢事上主, 悉不戒杀牲也。然而祭之前, 有散斋, 有致斋, 斋者悉不饮酒, 不茹荤。今 所见士大夫, 遇郊社大典, 咸断酒肉, 出居宫次。是则斋素之义, 不由释氏始, 不以杀牲故, 明矣。

Note 69. Xu, ‘A Comparative Study', p. 15.

Note 70. Liu, 'The Dubious Choice of an Enemy', pp. 224-238.

Note 71. Ibid, pp. 43-59.

Note 72. Gao, Late Ming Jesuits' Comments on Buddhism, p. 27.

Note 73. Xu Guangqi was a Chinese Catholic convert, scholar-bureaucrat, astronomer, agricultural scientist, and mathematician in the Ming dynasty. Xu was a collaborator and colleague of Sabatino de Ursis and the Italian Jesuits Matteo Ricci; with their helped, several classic Western texts are translated into Chinese, including some Elements of Euclid.

Note 74. Ricci, 'Ten Chapters of a Strange Man' (畸人十篇).

Note 75. Gao, Late Ming Jesuits' Comments on Buddhism, p. 28.

Note 76. Xu, 'A Comparative Study', p.12-15.

\section{Copyrights}

Copyright for this article is retained by the author(s), with first publication rights granted to the journal.

This is an open-access article distributed under the terms and conditions of the Creative Commons Attribution license (http://creativecommons.org/licenses/by/4.0/). 